\title{
The Effect of Company Growth, Current Ratio and Leverage Ratio of Dividend Policy in Trade, Services, and Companies Investment That is on The IDX
}

\author{
Holfian Daulat Tambun Saribu, Januardin \\ Universitas Prima Indonesia, Medan Helvetia, Medan 20124, Indonesia \\ Universitas Prima Indonesia, Medan Johor, Medan 20142, Indonesia \\ Email: holfiandts@yahoo.co.id, dan januardin@unprimdn.ac.id
}

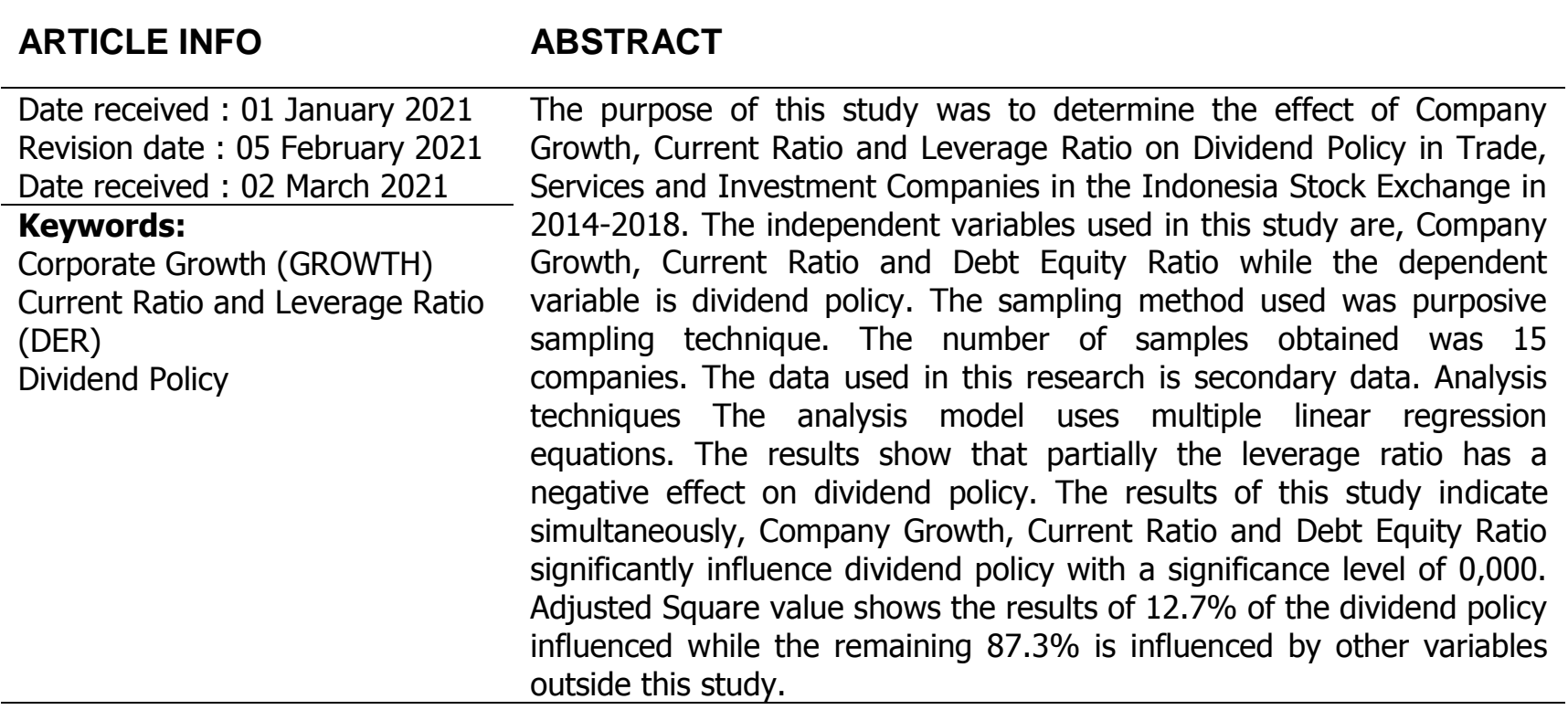

Coresponden Author:

Email: holfiandts@yahoo.co.id

Article with open access under license

\section{INTRODUCTION}

In the current era of development of the Globalization Era, the movement of business is very rapid, so that every company requires accuracy in making a business decision, especially investment, because investment is very important in the company, especially in carrying out its business activities. Investment decision return activities for company management and investors must be considered and considered properly to reduce the possibility of risks and uncertainties that will occur. Investment in the capital market is an investment in the field of financial assets which basically expects a return on the purchased securities. And keep in mind that investment choices always consider the level of profit expectancy and the level of risk. The expected level of profit can be in the form of dividends paid by the company (Agustina \& Andayani, 2016).

Dividends in principle are company profits distributed to shareholders. The purpose of the company was established is to prosper the owner of the company or shareholders while the main purpose of an investor in investing their funds is to obtain income, either in the form of dividend income or income from the difference between the selling 
price of shares against the purchase price. In other words, the dividend obtained is one of the investors to invest their funds in a company. Dividend distribution is a complicated matter in a company. In order to overcome this complexity, the management needs to supervise and align management interests with shareholders, one of which is by distributing cash dividends, which is the distribution of profits in cash (cash dividends).

Dividend policy is a decision to determine the amount of dividend that must be distributed to investors by involving two interested parties between management and shareholders and both have different expectations. Management expects retained earnings and shareholders expect dividends to be distributed. If a company runs a policy to distribute dividends, the funds that can be used by the company to finance its investment will be lower.

Investors want a relatively stable distribution of dividends with the stability of dividends maintained by a company to increase investor confidence in the company.

\section{Formulation Of The Problem}

Based on the background described earlier, the problem formulation in this study is as follows:

1. How does the growth of the Company (Growth) on Dividend Policy in the Trade, Services \& Investment Sectors listed on the Indonesia Stock Exchange in the period 2014-2018?

2. How does the Current Ratio (CR) influence on Dividend Policy in the Trade, Services \& Investment Sectors listed on the Indonesia Stock Exchange in the 2014-2018 period?

3. What is the effect of the Leverage Ratio (DER) on Dividend Policy in the Trade, Services \& Investment Sectors listed on the Indonesia Stock Exchange in the 2014-2018 period?

4. How is the influence, Company Growth (Growth), Current Ratio (CR) and Leverage Ratio (DER) on Dividend Policy in the Trade, Services \& Investment Sectors listed on the Indonesia Stock Exchange in the 2014-2018 period?

\section{Dividend Policy Theory}

According to Syahyunan (2013: 267), Dividend policy is a decision whether profits earned by a company at the end of the year will be distributed to shareholders in the form of dividends or will be retained to increase capital for future investment financing. According to Gumanti (2013: 7), dividend policy is a practice carried out by management in making dividend payment decisions, which include the amount of the rupiah, the pattern of cash distribution to shareholders. According to Harmono (2014: 12), dividend policy is the percentage of profits paid to shareholders in the form of cash dividends, maintaining dividend stability from time to time, dividend distribution of shares, and share buybacks.

\section{Theory of Company Growth (Growth)}

According to (Harahap, 2017) Harahap (2011: 309), the growth ratio (growth) illustrates the percentage growth of company posts from year to year. According to (Kasmir, 2016) the growth ratio is a ratio that illustrates the ability of a company to maintain its economic position amid economic growth and its business sector. According to (Fahmi, 2014), the growth ratio is a ratio that measures how much ability to maintain its position in the industry and in economic development in general.

\section{Current Ratio Theory (CR)}

According to (Houston, 2010), Current Ratio or current ratio is calculated by dividing current assets with current liabilities. This ratio shows the extent to which current liabilities are covered by assets that are expected to be converted into cash in the near future. According to (Munawir, 2018), explaining that "Current Ratio is the ratio between the amount of current assets to current debt, this ratio shows that the value of current assets (which can immediately be turned into money) has several times the short-term debt". According to Hani (2015: 121) Liquidity is the ability of a company to meet financial obligations that can immediately be disbursed or are due.

\section{Theory of Leverage (Debt Equity Ratio)}

According to (Raharjaputra, 2009), the Leverage Ratio is a ratio that measures how far or how large a company has been financed or financed by debt. According to (Prihadi, Hairul, \& Hazri, 2012), the solvency ratio (leverage) is a ratio to measure a company's ability to repay its debt. Debt can be compared with assets or own capital. According to (Munawir, 2018), Solvency is showing the company's ability to meet its financial obligations if the company is liquidated, both short-term and long-term financial obligations.

\section{Theory of Influence of Company Growth on Divided Policy}

According to (Sartono, 2008), the faster the company's growth, the greater the need for funds to finance expansion. The greater the future financing, the greater the desire of the company to hold profits. So companies that grow should not 
distribute profits as dividends but are better used for investment financing. According to (Riyanto, 2001), "The faster the company's growth rate, the greater the opportunity for profit, the greater the share of the income held in the company, which means that the ratio dividend payout is lower. According to (Rodoni., 2014), the faster the company's growth rate the greater the need to finance the development of the company's assets and the more funds needed in the future, the more profit must be retained and not to be paid to shareholders in the form of dividends (dividends) relatively small).

\section{Theory of Effect of Current Ratio on Dividend Policy}

According to (Kamaludin, 2011), "the greater the dividends paid, the smaller the liquidity position. Therefore, if the company's liquidity position is very good, then the more likely the ratio of dividend payments. According to (Gumanti \& Alkaf, 2014), if a company requires high liquidity, in this case it can be in the form of internal funding sources in the form of retained earnings, then dividends to be distributed should be reduced because paying dividends means cash disbursements and cash disbursements means a reduction in liquidity capability (meeting current liability). According to (Sudana, 2011), the higher the level of company liquidity, the greater the cash dividends that companies and shareholders can pay.

\section{Theories of the Effect of Leverage on Dividend Policy}

According to (Simbolon \& Riyanto, 2020), "debt can be paid off on the day of the fall by replacing the debt with new debt (refunding of debt). Or an alternative is that the company must provide its own funds that come from profits to pay off the debt. If the company determines that the repayment of its debt will be taken from retained earnings, it means that the company must withhold a large portion of its income for this purpose, which means that only a small portion of income or earnings can be paid low payout ratio ". According to (Sudana, 2011), "The greater the future funding needs, the greater the share of retained earnings in the company or the smaller dividends to be distributed to shareholders". According to (Sjahrial, 2014), "If the majority of profits are used to pay debts, the rest is used to pay dividends getting smaller".

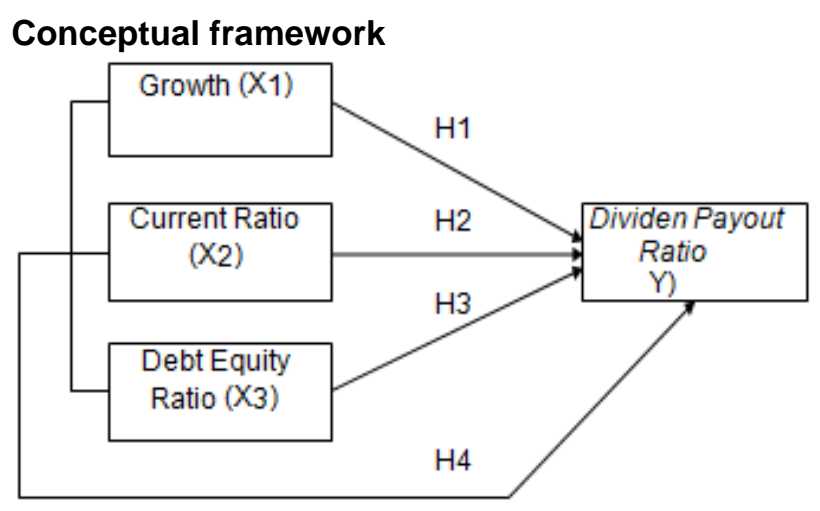

\section{METODE}

This research uses quantitative research methods. According to (Sugiyono, 2017) quantitative, namely a formulation of the problem relating to the question of the existence of an independent variable, whether only on a variable or more (an independent variable is a variable that stands alone). Quantitative data in this study are secondary data, namely financial statements published by the Indonesia Stock Exchange. the type of research used is descriptive statistics and the nature of this research is an explanatory relationship.

\section{Population}

The population used in this study is the Trade, Services and Investment sector companies in the 2014-2018 period listed on the Indonesia Stock Exchange in the form of financial reports sourced from the site www.idx.co.id, totaling 132 companies.

\section{Sample}

The sampling technique in this study uses the Purpose Sampling method, which is a sampling technique with certain considerations. In this study, the criteria set out are as follows: Trade, service, and investment companies listed on the Indonesia Stock Exchange for the period 2014-2018, trade, service, and investment companies listed on the Indonesia Stock Exchange that publish complete financial statements in successive periods. 20142018, Trade, service and Investment companies listed on the Indonesia Stock Exchange that use financial statements using the Rupiah currency for the 2014-2018 period, Trade, service, and investment companies listed on the Indonesia Stock Exchange that have positive profits in the period 2014-2018, Trade, service, and Investment companies that distribute Dividends in the 20142018 period.

Definition of Operational Research Variables 
In this study the operational definition of the Independent variable namely leverage, company growth and current ratio and the Dependent variable namely dividend policy as follows:

1. Company Growth

According to Harahap (2015: 309) the formula to find the growth ratio can be used as follows:

Increase in sales $=$ This year's sales - last year's sales

2. Current Ratio (CR)

last year's sales

According to Brigham \& Houston (2012: 134), the

current ratio is calculated by:

Current Ratio $=$ Current assets

Current liabilities

3 Leverage (Debt to Equity Ratio)

According to Darmadji and Fakhrudin (2012: 158)

"The ratio of debt to equity is a ratio that measures the extent to which the amount of debt can be covered by the model itself." this ratio is calculated as follows:

Debt Equity Ratio $=\underline{\text { Total Amoun of debt }}$

4. Dividend Payout Ratio (DPR) Equity

According to Ambarwati (2010: 66), dividend payout ratio indicators can be measured using the formula:

Dividend Payout Ratio $=$

Dividen

Earning Aftar Taxes

\section{Data analysis technique}

Classical Assumptions

1. Normality test

It aims to test whether in the regression model, confounding or residual variables have a normal distribution. There are two ways, namely graph analysis and statistical tests

2. Multicollinearity Test.

Multiconiearity test aims to test whether the regression model found a correlation between independent variables (independent).

3. Autocorrelation Test

It aims to test whether in the linear regression model there is a correlation between confounding errors in the previous $\mathrm{t}-1$ period.

Tabel 1 Descriptive Statistics

\begin{tabular}{lcrrrr}
\hline & $\mathrm{N}$ & Minimum & Maximum & \multicolumn{1}{c}{ Mean } & \multicolumn{1}{c}{ Std. Deviation } \\
\hline Delta_Sales & 75 & -.1768 & .3974 & .083130 & .1149801 \\
CR & 75 & .8651 & 7.2612 & 2.321909 & 1.4732744 \\
DER & 75 & .8651 & 7.2612 & 2.321909 & 1.4732744 \\
DPR & 75 & .0344 & 1.2393 & .314208 & .2438030 \\
Valid N & 75 & & & & \\
(listwise) & & & & & \\
\hline
\end{tabular}

d. Heterokesdatisitas test.

It aims to test whether in a regression there is a similarity in the variance of residuals from one observation to another.

\section{Research Data Analysis Model}

\section{Multiple Linear Analysis}

Testing the hypothesis used in this study is to use multiple linear regression analysis. The regression model used is as follows:

$$
\begin{aligned}
& Y=a+b 1 X 1+b 2 \times 2+b 3 \times 3+e \\
& \text { Information : } \\
& Y=\text { Dividend } \\
& a=\text { constant } \\
& \text { b1, b2, b3 = Regression Coefficient } \\
& \text { X1 = Company Growth Variable } \\
& \text { X2 = Current Ratio Variable } \\
& \text { X3 = Leverage Variable } \\
& \text { e = Standard Error }(5 \%)
\end{aligned}
$$

2. Determination Coefficient Test (R2)

According to Ghozali (2013: 95) the coefficient of determination (R2) is used to test or measure how far the ability of the independent variables to explain the dependent variable. The coefficient of determination is between zero and one. If the coefficient of determination (R2) is small, it means that the ability of the independent variable in explaining the dependent variable is very limited. If the value is close to one, it means that the independent variable provides almost all the information needed to predict the dependent variable.

3. Simultaneous Test (F-Test)

According to (Pamungkas, Ghozali, Achmad, Khaddafi, \& Hidayah, 2018) Simultaneous Test F test is used to determine whether the independent variable (independent) together or simultaneously affect the dependent variable (bound).

\section{Partial Test (t-Test)}

According to (Pamungkas et al., 2018) the statistical test $t$ basically shows how far the influence of one explanatory / independent variable individually in explaining the variation of the dependent variable.

\section{RESULTS AND DISCUSSION Descriptive statistics}

Descriptive statistics of the variables used in this study are presented in the following table:

Fig 1. Descriptive Statistics

Source: SPSS output, 2020

\section{Classic assumption test}

The classic assumption test is a statistical requirement that must be met to carry out a linear regression analysis, it aims to find out whether the data examined has met the eligibility requirements in the study. The classic assumption test 
requirements that must be met by multiple linear regression models are: normality test, multicollinearity test, autocorrelation test, and heterokedasticity test.

\section{Classic Assumption Test Results 1. Normality Test}

Normality Test aims to test whether the regression of confounding or residual variables has a normal distribution. Normality test used to test whether or not normal distribution is by graphical and statistical analysis.

a. Histogram Graph

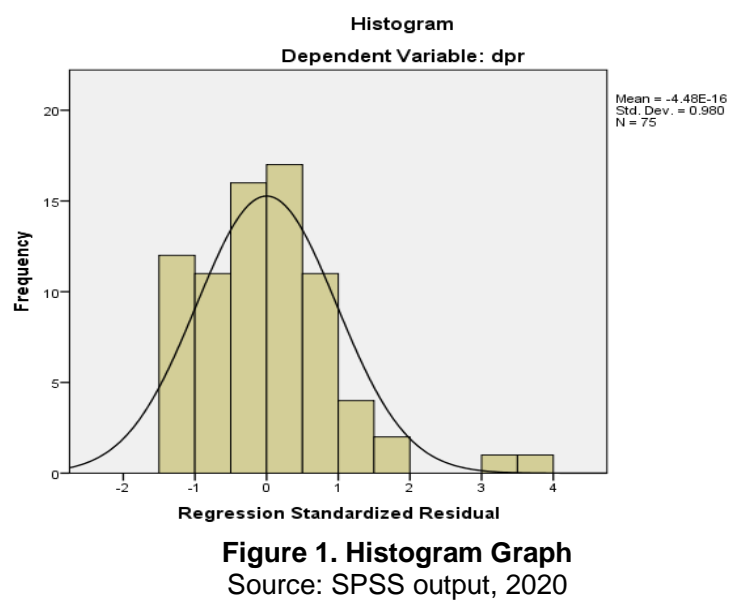

On the histogram graph, it can be seen that the graph is normally distributed. Normality test results with histogram graphs show a bell-shaped curve or tend to be symmetrical $(U)$ without deviating to the left or right.

b. Normal Probability Plot

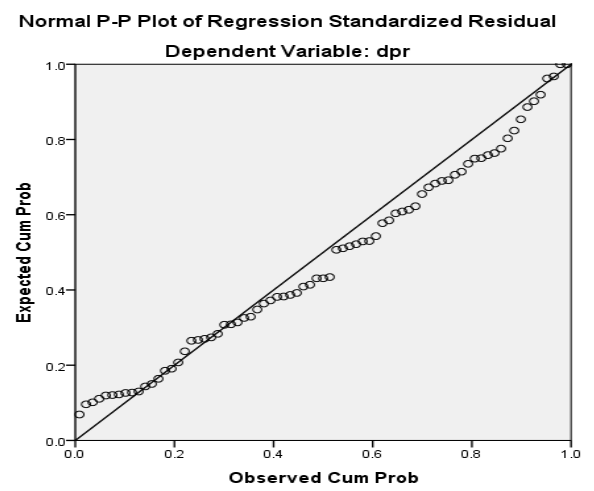

Figure 2. P-Plot Graph

Source: SPSS output, 2020

In the P-plot graph IV.2 can be seen the points spread along the diagonal lines, it can be concluded that the data in the regression model are normally distributed.

\section{Multicollinearity Test}

Multicollinearity Test aims to show whether there are independent variables that have a strong relationship with other independent variables in the regression model.

Table 3

\section{Coefficients $^{\mathrm{a}}$}

\section{Multicollinearity Test}

\begin{tabular}{llll}
\hline Model & \multicolumn{2}{c}{ Collinearity Statistics } \\
\cline { 2 - 4 } & \multicolumn{2}{c}{ Tolerance } & \multicolumn{1}{c}{ VIF } \\
\hline \multirow{3}{*}{1} & & & \\
\cline { 2 - 4 } & Delta_penjualan & .993 & 1.007 \\
\cline { 2 - 4 } & CR & .643 & 1.555 \\
\cline { 2 - 4 } & DER & .646 & 1.547 \\
\hline
\end{tabular}

a. Dependent Variable: DPR

Source: SPSS output, 2020

Based on the table above, conclusions can be made as follows: The Company Growth Variable (X1) has a Tolerance value of $0.993>0.10$ and a VIF value of $1.007<10$, Current Ratio Variable (X2) has a Tolerance value of $0.643>0.10$ and a VIF value of $1.555<10$, Leverage (X3) has a Tolerance value of $0.646>0.10$ and a VIF value of $1.547<10$, so it is concluded that the data variable debt equity ratio, company growth, and current ratio do not occur symptoms of multicollinearity.

\section{Heterokedastisitas Test}

Heterokedastisitas test aims to test whether in the regression model there is a variable inequality from residuals of an observation to another observation. Heterokedastisitas test is done by using a graph scatterplot and glacier test.

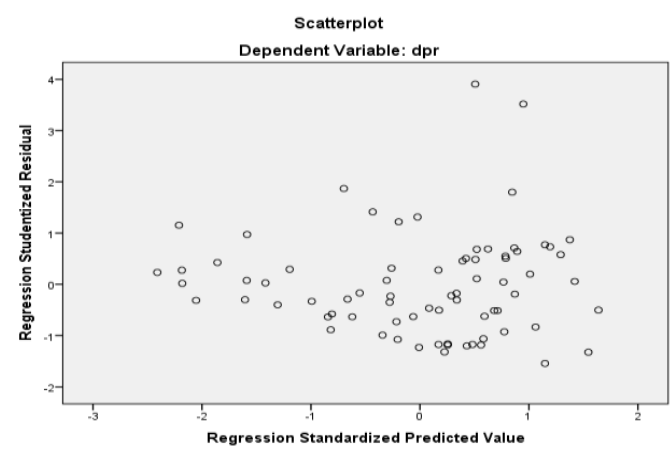

Figure 3. Scatterplot graph

Source: SPSS output, 2020

In the figure above the Scatterplot chart shows that the points spread randomly and spread both above and below the zero on the $Y$ axis. It can be concluded that there is no heterokedasticity in the regression model, so that the regression model is feasible to use. 


\section{Autocorrelation Test}

Autocorrelation test aims to see whether in a linear model there is a correlation between the error of the intruder in the period $t$ with an error in the period $\mathrm{t}-1$ (previous). In the autocorrelation test using Durbin-Watson (DW) to overcome the autocorrelation problem with the criteria $\mathrm{du}<\mathrm{dw}$ $<4-d u$. The following is the autocorrelation test with the Durbin-Watson (DW) test.

Table 4 Autocorrelation Test

\begin{tabular}{|c|c|c|c|c|c|}
\hline \multicolumn{6}{|c|}{ Model Summary } \\
\hline $\begin{array}{l}\text { Mo } \\
\text { del }\end{array}$ & $\mathrm{R}$ & $\begin{array}{c}\text { R } \\
\text { Square }\end{array}$ & $\begin{array}{l}\text { Adjusted R } \\
\text { Square }\end{array}$ & $\begin{array}{l}\text { Std. Error of } \\
\text { the Estimate }\end{array}$ & $\begin{array}{l}\text { Durbin- } \\
\text { Watson }\end{array}$ \\
\hline 1 & .403 & .163 & .127 & 2277798 & 1.995 \\
\hline
\end{tabular}

a. Predictors: (Constant), cr, sales, der

b. Dependent Variable: dpr

Source: SPSS output, 2020

Based on the table above shows that the results of the Watson Durbin test show that the Durbin Watson value obtained is 1.995 while in the DW table for "K" $=4$ (number of variables) the $d u<d w$ $<4$-du test. The value of $\mathrm{dl}$ and du in this study with a total of 4 variables 75 (number of samples) is the value of $\mathrm{dL}=1.5151$ and $\mathrm{dU}=1.7390$. The $\mathrm{DW}$ value obtained is greater than the $\mathrm{dU}$ value and smaller than the value $(4-\mathrm{du}=4-1.7390=$ 2.261 ) which is $1.7390<1.995<2.261$ so that it can be concluded that $\mathrm{HO}$ is accepted ie there is no autocorrelation in the regression model of this study and $\mathrm{Ha}$ is rejected, which means there is no autocorrelation.

\section{Multiple Linear Regression Analysis}

Testing the hypothesis used in this study is to use multiple linear regression analysis. The regression model used is as follows:

Table 5

\section{Test models for Multiple Linear Regression} Analysis Coefficients $^{\mathrm{a}}$

\begin{tabular}{|c|c|c|c|}
\hline \multirow{2}{*}{\multicolumn{2}{|c|}{ Model }} & \multicolumn{2}{|c|}{$\begin{array}{l}\text { Unstandardized } \\
\text { Coefficients }\end{array}$} \\
\hline & & $B$ & Std. Error \\
\hline \multirow{4}{*}{1} & (Constant) & .416 & .091 \\
\hline & Delta_Sales & -.418 & .231 \\
\hline & $\mathrm{CR}$ & .014 & .022 \\
\hline & DER & -.105 & .047 \\
\hline
\end{tabular}

a. Dependent Variable: DPR

Source: SPSS output, 2020
Based on the table above obtained by the multiple linear regression equation as follows:

Dividend Policy $=0.416-0.105$ (Company Growth) +0.014 (Current Ratio) + e (Leverage) - 0.418

Interpretation results from the regression are as follows:

1. A value (constant) of 0.416 means that if the variable Company Growth (X1), Current Ratio (X2) and Debt Equity Ratio (X3) are considered constant, then the dividend policy is 0.416

2. The Company Growth Coefficient $\left(X_{1}\right)$ of 0.418 shows that each increase in Corporate Growth is one unit, the Dividend Policy decreases by 0.418 units.

3. Current Ratio $\left(X_{2}\right)$ coefficient value of 0.014 shows that every increase in Current Ratio is one unit, the Dividend Policy has increased by 0.014 units

4. Debt Equity Ratio $\left(X_{3}\right)$ Coefficient of - 0.105, this shows that every increase in Debt Equity Ratio of one unit, the Dividend Policy has decreased by 0.105 units

\section{Coefficient of Determination}

The coefficient of determination (R2) is a number that shows the degree or degree of distribution of the independent variable $(X)$ in explaining and explaining the dependent variable $(Y)$. In this study using Ajusted R2 when evaluating the best regression model. Here is the coefficient of determination:

Table 6

Coefficient of Determination

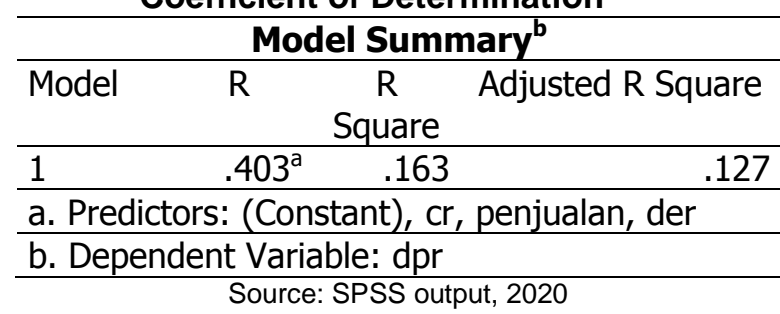

Based on the table above the determination coefficient test results obtained adjusted $\mathrm{R}$ square value (R2) determination coefficient of 0.127 or equal to $12.7 \%$ of the independent variable (dividend policy) can be explained by variations of the independent variables namely: Debt equity ratio, company growth and Current ratio while the remaining $87.3 \%$ is influenced by other variables. 


\section{Test $F$}

The $\mathrm{F}$ test is used to test whether the independent variables together influence the dependent variable.

Table 7 Test $F$

\begin{tabular}{lccrrr}
\hline \multicolumn{6}{c}{ ANOVA $^{\text {a }}$} \\
\hline Model & $\begin{array}{c}\text { Sum } \\
\text { of } \\
\text { Squar } \\
\text { es }\end{array}$ & $\begin{array}{c}\text { Mean } \\
\text { Df }\end{array}$ & $\begin{array}{l}\text { Squar } \\
\text { e }\end{array}$ & F & Sig. \\
\hline $\begin{array}{l}\text { Regressi } \\
\text { on }\end{array}$ & .715 & 3 & .238 & 4.59 & .005 \\
1 & & & & 2 & b \\
\hline Residual & 3.684 & 71 & .052 & & \\
\hline Total & 4.399 & 74 & & & \\
\hline
\end{tabular}

a. Dependent Variable: dpr

b. Predictors: (Constant), cr, penjualan, der Source: SPSS output, 2020

From the table above, the $\mathrm{F}$ test results can be seen that together the independent variables have significant and significant effects on the dependent variable. The simultaneous test results (Test F) can be proven from the Fcount value of 4.592 with a significant value of 0.005 while the Ftable of 2.73 with a significance of 0.05 . df 1 (number of variables - 1) $=3$ and df2 $(n-k-1)=(75-3-1)=71$, a Ftable of 2.73 is obtained. So it can be concluded that Fcount $>$ Ftable $(4,592>2.73)$ with a significant value of $0.005 \leq 0.05$. Then $\mathrm{Ha}$ is accepted and $\mathrm{HO}$ is rejected, which means company growth, Current Ratio and Leverage simultaneously have a significant effect on Dividend Policy on Trade, Services and Investment companies listed on the Indonesia Stock Exchange for the period 20142018.

\section{Test $t$}

The $t$ test is used to test whether the independent variables individually affect the dependent variable. Table 8. Test $t$

\begin{tabular}{|c|c|c|c|c|c|c|}
\hline & & & Coefficien & & & \\
\hline & & Unsta & idardized & Standardized & $\mathrm{T}$ & Sig. \\
\hline & & $B$ & Std. Error & Beta & & \\
\hline & (Constant) & .416 & .091 & & 4.589 & .000 \\
\hline & Delta_penjualan & -.418 & .231 & -.197 & -1.809 & .075 \\
\hline 1 & CR & .014 & .022 & .082 & .608 & .545 \\
\hline & DER & -.105 & .047 & -.303 & -2.245 & .028 \\
\hline a. & Dependent Var & $\begin{array}{l}\text { DPR } \\
\text { So }\end{array}$ & ree: S & ut, 2020 & & \\
\hline
\end{tabular}

The results of the above table test the hypothesis of each independent variable partially on the dependent can be analyzed as follows:

Company Growth $\left(\mathrm{X}_{1}\right)$ obtained t-count of 1,809 and ttable 1,993 or - ttest <- ttable $(-1,809$ $<1,993)$ with a significant value of $0.075>0.05$ then $\mathrm{HO}$ is accepted $\mathrm{Ha}$ is rejected, which means that $\Delta$ Sales partially have no significant effect on
Dividend Policy on Trade, Services and Investment companies listed on the Indonesia Stock Exchange in the 2014-2018 period.

Current Ratio $\left(X_{2}\right)$ obtained tcount of 0.608 and $\mathrm{t}$ table 1.993 or tcount $>\mathrm{t}$ table $(0.608<1.993)$ with a significant value of $0.545>0.05$ then $\mathrm{HO}$ is accepted $\mathrm{Ha}$ is rejected which means that the Current Ratio partially has no significant effect on Dividend Policy on Trade, Services and Investment companies listed on the Indonesia Stock Exchange in the 2014-2018 period.

Debt Equity Ratio $\left(\mathrm{X}_{3}\right)$ obtained $t$ count of 2.245 and $\mathrm{t}$ table 1.993 or - tcount $>$ - $\mathrm{t}$ table (2.245> 1.993) with a significant value of 0.028 $<0.05$ then $\mathrm{HO}$ is rejected $\mathrm{Ha}$ is accepted which means that Debt Equity Ratio partially influences negative and significant towards the Dividend Policy on Trade, Services and Investment companies listed on the Indonesia Stock Exchange in the 2014-2018 period.

\section{CONCLUSION}

Based on the results of this study is about the findings and concordance of theories, opinions, and previous studies that have been found before. Following are the findings in this study:

Company growth does not significantly influence Dividend Policy. Company growth $\left(X_{1}\right)$ is obtained t-count of $-1,809$ and ttable 1,993 or ttest <- ttable $(-1,809<1,993)$ with a significant value of $0.075>0.05$ then $\mathrm{HO}$ is rejected $\mathrm{Ha}$ is accepted, which means that $\Delta$ Selling partially has no significant effect on Dividend Policy in the Trade, Services and Investment companies listed on the Indonesia Stock Exchange for the period 20142018.

Current Ratio does not significantly influence Dividend Policy. Current Ratio $\left(\mathrm{X}_{2}\right)$ obtained tcount of 0.608 and $t$ table 1.993 or tcount $>t$ table $(0.608$ $<1.993$ ) with a significant value of $0.545>0.05$ then $\mathrm{HO}$ is accepted $\mathrm{Ha}$ is rejected which means that the Current Ratio partially has no significant effect on Dividend Policy in the Trade company, Services and Investment listed on the Indonesia Stock Exchange in the 2014-2018 period.

Leverage Ratios have a significant negative effect on Dividend Policy. Where a comparison tcount $>$ - $\mathrm{t}$ table $(-2.245>1.993)$ with a significant value of $0.028<0.05$ then $\mathrm{HO}$ is rejected $\mathrm{Ha}$ is accepted, which means that Debt Equity Ratio $\left(X_{3}\right)$ partially has a significant negative effect on Dividend Policy in the Trade, Services and Investment listed on the Indonesia Stock Exchange for the period 2014-2018. 
The results of the $\mathrm{F}$ test can be proven from the $F$ value of 4.592 with a significant value of 0.005 while the $F$ table of 2.73 with a significance of 0.05 . Thus it can be concluded Fcount> Ftable $(4,592>2.73)$ with a significant value of $0.005 \leq$ 0.05 . Then $\mathrm{Ha}$ is accepted and $\mathrm{HO}$ is rejected, which means leverage, company growth, and current ratio simultaneously have a significant effect on dividend policy on trade, service and investment companies listed on the Indonesia Stock Exchange in the 20142018 period.

Every investor must pay attention to the variable company growth, leverage which significantly influences the dividend policy before making a decision in making capital market investments. For further research, research should not only use one sample but all companies listed on the IDX by adding variables that have not been examined in this study.

\section{REFERENCES}

Agustina, Liya, \& Andayani, Andayani. (2016). Pengaruh Kinerja Keuangan, Ukuran Perusahaan, dan Pertumbuhan Perusahaan terhadap Kebijakan Dividen. Jurnal Ilmu Dan Riset Akuntansi (JIRA), 5(10).

Fahmi. (2014). Pengantar Manajemen Keuangan (Cetakan ke). Bandung: Alfabeta.

Ghozali, Imam. (2011). Application of multivariate analysis with SPSS program. Semarang: Diponegoro University Publishing Agency.

Gumanti, Tatang Ary, \& Alkaf, Nafisah. (2014). Underpricing dalam Penawaran Saham Perdana dan Penawaran Saham Susulan. Jurnal Akuntansi Dan Keuangan Indonesia, 8(1), 21-35.

Harahap, R. A. (2017). Etika dan Hukum Kesehatan.

Houston, Eugene F. Brigham and Joel F. (2010). Dasar-Dasar Manajemen Keuangan. Jakarta: Salemba Empat.

Kamaludin, D. R. (2011). Manajemen Keuangan "Konsep Dasar dan Penerapannya." Bandung: CV Mandar Maju.

Kasmir, Anoli. (2016). Myoron Kruonpon. Jakarta: Raja Grafindo Persada.

Munawir, Slamet. (2018). Analisa laporan keuangan. Liberty.

Pamungkas, Imang Dapit, Ghozali, Imam, Achmad,
Tarmizi, Khaddafi, Muammar, \& Hidayah, Retnoningrum. (2018). Corporate governance mechanisms in preventing accounting fraud: A study of fraud pentagon model. Journal of Applied Economic Sciences, 13(2), 549-560.

Prihadi, Kususanto, Hairul, Nizam Ismail, \& Hazri, Jamil. (2012). Mediation Effect of Locus of Control on the Causal Relationship between Students' Perceived Teachers' Expectancy and Self-Esteem. Electronic Journal of Research in Educational Psychology, 10(2), 713-736.

Raharjaputra, Hendra S. (2009). Buku Panduan Praktis Manajemen Keuangan dan Akuntansi untuk Eksekutif Perusahaan. Salemba Empat. Jakarta.

Riyanto, Bambang. (2001). Dasar-dasar pembelanjaan perusahaan.

Rodoni., Ali dan. (2014). Manajemen Keuangan Modren. Ed. Asli, : Jakarta: Mitra Wacana Media.

Sartono, Sartono. (2008). Improving Student's Vocabulary Mastery By Using Direct Method (DM) At The Fourth Year Students Of Sdn 02 Jaten Juwiring Klaten In 2007/2008 Academic Year (A Classroom Action Research). Universitas Muhammadiyah Surakarta.

Simbolon, Refli, \& Riyanto, Setyo. (2020). How Retail Survive Against Pandemic of COVID-19: An Insight from Optical Retailer. International Journal of Current Science and Multidisciplinary Research, no-124.

Sjahrial, Dermawan. (2014). Manajemen keuangan lanjutan. Jakarta: Mitra Wacana Media.

Sudana, Imade. (2011). Manajemen Keuangan Perusahaan: Teori \& Praktik.

Sugiyono. (2017). Metode Penelitian Kuantitatif, Kualitatif, dan R\&D. Bandung: CV. Alfabeta. 